\title{
REVIEW
}

\section{Is Compulsory School a Heaven or a Hell?}

\section{Liuyi Yang $^{1^{*}}$ Yujie Liu ${ }^{2}$}

1. Northeast Normal University, Changchun, Jilin, 130024, China

2. Harbin University, Harbin, Heilongjiang, 150086, China

\begin{tabular}{l} 
ARTICLE INFO \\
\hline Article history \\
Received: 4 September 2019 \\
Revised: 16 September 2019 \\
Accepted: 9 October 2019 \\
Published Online: 16 October 2019 \\
\hline Keywords: \\
Compulsory education \\
Human rights \\
Education wisdom \\
Educational equity
\end{tabular}

\section{Introduction}

$\mathrm{C}$ ompulsory education, which refers to a period of education that is required of all people and is imposed by government, takes place at a registered school (schooling) or at home (homeschooling). ${ }^{[1]}$ Nowadays, the topic of compulsory education is being discussed intensely which not only because some people think that the educational system has some inevitable problems, but also because of different people's various of perspectives.

Lynda Barry and John Taylor Gatto are representative examples who argue whether the compulsory school provides freedom or not. In the article "The Sanctuary of School", which is written by Lynda Barry, the author compares her school to a sanctuary, which provides her a home-

\begin{abstract}
With the development of education and the society revolution, in the last few years, the word "freedom" has been discussed intensely, and the debates on some items like human rights, racial discrimination and political liberty have never stopped. At the same time, the discussion of freedom in the field of education is also rising. This article quotes Lynda Barry and John Taylor Gatto's paper, clearly analyzing the effect of compulsory education through 3 aspects: national identity, creative approach and personal psychology.
\end{abstract}

like zone and comforts her when she is suffering from her unhappy family. On the contrary, John Taylor Gatto, who is the author of "Against School", fiercely criticizes the drawbacks of compulsory education. Actually, Barry and Gatto both agree that compulsory school provides students a national identity, which has a positive outcome towards their government. However, at the same time, they focus on different points of view. Barry holds the view that compulsory school is a comfortable place which provides freedom and respect for students, but Gatto disagrees with Barry's point of view, as he argues that the compulsory educational system is a heavy fetter which limits the development of people's thinking. Through these two articles, we can say that they agree with each other on the function of national

\footnotetext{
*Corresponding Author:

Liuyi Yang,

Northeast Normal University, No. 2555 Jingyue Street, Nanguan District, Changchun, Jilin, 130024, China

E-mail:936549391@qq.com.

Fund Project:

Heilongjiang Province Education Science Planning Subject (Project No.: GJC1318053).
} 
identity which means that education works for government. However, Barry believes that compulsory school also provides some creative educational methods like painting, which is opposed to Gatto's idea. Also, Gatto regards students as products on the assembly line, which challenges the basic ideas about compulsory school set out by Barry.

\section{Compulsory School Works for the Govern- ment, Because It Fosters National Identity}

It leads students to pay attention to their freedom which is for free and mature people. To show that teachers are loyal to their country, Barry states, "Mrs. LeSane asked us to stand, face the flag, place our right hands over our hearts and say the Pledge of Allegiance. Children...do it faithful$1 y$ "[1]. As a famous Chinese saying goes, "A teacher is a mirror of children." Also, the famous educational psychologist called Jerome Seymour Bruner thinks that teachers are not only disseminators of knowledge, but also models. ${ }^{[3]}$ What a teacher does strongly reflects his/her students. Although the flag-rising ceremony seems to be formalistic, Mrs. LeSane requires students to express their highest respect for their nation to enhance their national consciousness. She does not force her students to do so, but it is obvious that her students love this country from the bottom of their hearts, which means that the compulsory education she represents is successful. Similarly, in Gatto's article, people can see another way to express patriotism. As Gatto states, "the Prussian system was useful in creating not only a harmless electorate and a servile labor force but also a virtual herd of mindless consumers" ${ }^{,[]}$. The compulsory education system Gatto mentions is efficient and positive for government. By telling students some social rules in compulsory school, the government and teachers make sure that students understand how doing with consciousness is the best for government. The closed education method helps government perfectly do their jobs, but under this system, compulsory school will educate many foolish people. Barry and Gatto both agree that education creates people's national identity, although they have different perspectives.

\section{Barry Agrees that Her Compulsory School Implements Some Creative Educational Ap- proaches, Like Painting, to Make Students More Imaginative, Gatto Challenges Her Idea, Because She Thinks That Compulso- ry School Focuses On Routine Teaching by a Spoon-Feeding Teaching Method That Is Hard to Change}

To show her teacher's unique educational method, Bar- ry remembers, "to sit apart from the class for a while to paint, draw and silently work out impossible problems on $11 \times 17$ sheets of newsprint" ${ }^{, 2]}$. Her teacher treats students well and helps them release negative energies through a literary and artistic way, which is called "quality education". The reform of compulsory education in the United States is a balanced development process in pursuit of fairness as a whole. Its ultimate goal is to achieve educational fairness, protect people's basic rights and adapt to the development of modernization. ${ }^{[5]}$ Teachers in Barry's school give students chances to express themselves through paintings, it makes students regard their school as a heaven. As a detail, the phrase "silently work" shows Berry thinks school provides an independent thinking space to students and gives students chances to relieve suffering. Also, these kinds of activities help students to forget the pains that they are going through, and help teachers show enough respect and give enough freedom for students. In Gatto's article, he states, "I don't mean education, just forced schooling: six classes a day, five days a week, nine months a year, for twelve years" ${ }^{\text {[4] }}$. He compares compulsory school as forced education which shows a feeling of debility. He is questioning and challenging the current educational system. Students have no chance to challenge the inherent concepts that are strongly rooted in traditional people's mind. Actually, to help students break out of the boring system, Gatto tries to defy custom or even to disobey the law. However, he states, "the empire struck back, of course; childish adults regularly conflate opposition with disloyalty" ${ }^{\text {"[4] }}$. The statement tells us that his attempt is regarded as a kind of disloyalty, which makes people bitterly disappointed. Through Barry and Gatto's detailed descriptions, we can see that Gatto challenges Barry's idea about compulsory school's educational methods, which makes the central point stronger.

\section{Barry Supports That Teachers Are the Ones Who Care About Students' Daily Life And Do Some Psychological Counseling For Students. However, Gatto Regards Students as Products on the Assembly Line and Who Must Obey the Principle of Theory of Natu- ral Selection}

Strengthening children's education, improving the protection of children's rights and making them develop healthily and thrive are gradually becoming one of the overall and strategic tasks of governments and the international community. ${ }^{[6]}$ As Barry states, "We were children with the sound turned off. As... neglected children in this country, the only place where we being noticed 
was at school" "2]. We can assume that school has a high position in students' mind when they feel upset through Barry's article. She also expresses that it is a serious social problem that children are not that important for a family. In her opinion, schools not only undertake the responsibility to teach basic knowledge, but teachers focus on students' mental health and treat students as if they were their own children. Students feel free and respected. In Gatto's article, he states, "The aim... is simply to reduce as many individuals as possible to the same safe level, to breed and train a standardized citizenry, to put down dissent and originality" ${ }^{[4]}$. This kind of education is very terrible for students whose world outlooks have not formed yet, because compulsory schools do not treat students as human beings nor do they focus on human rights. It will help students form an enslaved world outlook. Schools adopt the selective function which is similar to Charles Robert Darwin's theory of survival of the fittest. The awful atmosphere makes compulsory school seems like a hell. Actually, in 1959, the Convention on the Rights of the Child agrees "Principle of the Best Interest of Children", which means that children's human rights had been valued by so-called "adults". In the process of education, children should be the subject of rights and government has to fulfill obligations from this perspective. Barry and Gatto hold opposite points of view towards schools' responsibilities.

\section{Conclusion}

All in all, the relationship between freedom and education is strong, and people may never stop debating about whether a compulsory school is a heaven or a hell. However, through American compulsory educational system, there are some advantages, such as the specific structure of responsibility division, the $50 \%$ proportion of investment in primary education and special expenditure items, etc., which is also helpful for other countries in developing compulsory education. ${ }^{[8]}$ Education is a kind of process which has responsibilities to educate independent people. Using different cruel methods on students disobeys the original desire of education. Giving students enough freedom and recalling some of unnecessary rights are better alternative for compulsory schools. Hopefully, educational system can truly beneficial to students and the world will be better, because children are the future of a nation.

\section{References}

[1] From Wikipedia,available at https://en.wikipedia.org/ wiki/Compulsory_education.

[2] Linda Barry. "The school' s sanctuary." The New York Times, 1992.

[3] "Piaget and Bruner's Harmony and Integration and Development_ - On the Triple Depth of Basic Theories of Educational Technology" Zheng Xudong, Chen Rong, Ouyang Chenchen. Huazhong Normal University School of Education and Information Technology.

[4] John Taylor Gato. "Objection against the school." Harpers Magazine, 2003.

[5] "Research on American Compulsory Education Reform under the Vision of Fairness" Wang Yu. Southwest University.

[6] "International Law Research on the Protection of Children's Rights" Wang Yongmin. East China University of Political Science and Law.

[7] "On the obligation of compulsory education" Guo Wei. Xiangtan University.

[8] "The Responsibility of Compulsory Education of Governments at Different Levels in the United States and Its Enlightenment to China" Yan Yanqun. Zhejiang University of Finance and Economics. 